\title{
Anthropometric Study of Philtrum (Face) and other nasal parameters in Nepal
}

\author{
Sanjay Kumar Yadav ${ }^{1}$, Banshi Krishan Malla ${ }^{1}$, Ashok Kumar Srivastava ${ }^{2^{*}}$, \\ Ram Prasad Timsina ${ }^{1}$, Nityanand Srivastava ${ }^{3}$, Alok Kumar ${ }^{4^{*}}$

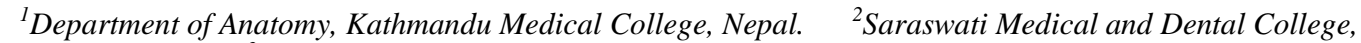 \\ Lucknow, India. ${ }^{3}$ Department of Anatomy, Uttar Pradesh University of Medical Sciences, Saifai, Etawah. - \\ 206130 (U.P.) India. ${ }^{4}$ Department of Forensic Medicine \& Toxicology, Uttar Pradesh University of Medical \\ Sciences, Saifai, Etawah. -206130 (U.P.) India. \\ *Corresponding Authors: Dr. Alok Kumar, \\ E.mail: $\underline{\text { drsalok@rediffmail.com \& Dr Ashok Kumar Srivastava, E.mail: ashokuru@yahoo.com }}$
}

(Received 19 April 2018; Accepted 11 June 2018; Published 5 September 2018)

\begin{abstract}
Aim and Objective: The philtrum plays a key role in appearance of upper lip and nostril. Present study aims to determine and compare the philtrum and other nasal parameters of male and female Nepalese, and to provide a comprehensive data for use by anthropologists and medical practitioners. Materials and Methods: This cross sectional study involves 400 medical students aged 17-25 years (200 males and 200 females) at Kathmandu Medical College Nepal. Results: The test of significance was done using independent t-test and ANOVA. It was observed that the parameters of nose height $(50.813$ $\mathrm{mm} \pm \mathrm{SD} 4.53$ ), nose length (49.38 $\mathrm{mm} \pm \mathrm{SD} 4.56)$, nose depth (19.81 $\mathrm{mm} \pm \mathrm{SD} 2.21$ ), Philtrum length (13.63 $\mathrm{mm} \pm \mathrm{SD} 2.35)$, philtrum width (11.53 $\mathrm{mm} \pm \mathrm{SD} 1.23)$ and columella width $(6.323 \mathrm{~mm} \pm \mathrm{SD} 0.64)$ were significant $(\mathrm{p}-0.001)$ whereas nose width (49.38 mm \pm SD 4.56) was not significant ( $\mathrm{p}=0.295)$ among male and female. In general, philtrum and Nasal parameters analyzed are larger in males. Conclusion: The study population has mesorrhine type of nose. All aspects of nose and philtrum, at least those considered here, are highly sexually dimorphic. These findings can be utilized for various purposes in physical anthropology, forensic science and clinical practice and will also provide a future framework for the evaluation of other craniofacial variables in same population.
\end{abstract}

Key words: Anthropometry; Forensic Science; Face; Nose; Philtrum; Columella; Mesorrhine; Nepal. 


\section{Introduction}

Measurement of human beings to understand their physical variation has been a long time practice, known as anthropometry. It stems from the measurement of the whole human body to individual body parts e.g. face, nose, limb and orbit. In ancient times, it was used in criminology where criminals were identified by measuring parts of their body. During the early 20th century, one of primary uses of anthropometry was to try to class races within human kind. But after the development of the genetic field and the discovery of the genetic and molecular markers, studies of human populations showed that there is no biological reality to human race.

Nasal anthropometry is the measurement of the different parameters of the nose. It is considered as one of the best clues to look for the ethnic group origin (Franciscus et al. 1991, Madison. 2004). The nose is the uppermost part of the respiratory tract and the organ for smell. Its shape (including the nasal bridge, slope of the tip, septum and nares) differs from one population (or ethnic group) to another and from one environmental region of the world to the other. Thus, nasal index is the most common nasal parameter which may be related to regional and climatic differences, with longer narrower noses in cold and dry climate while broader noses are seen in warmer, moisten region (for review see Zaidi et al. 2018).

The Philtrum plays a key role in the appearance of the upper lip and nostril sill. Therefore, construction of the philtrum is crucial for attaining a natural appearance of the lip. The philtrum, which derive from the Greek word philtron meaning "love potion" is the most characteristic feature of the upper lip, helping to create a natural appearance of the lip (Know et al. 2008). It is observed that during motion, the philtrum column and dimple are highlighted, helping a viewer from an impression of the speaker. It is also showed morphological philtrum disorders occur in patients with cleft lip, secondary cleft lip, nose deformity and deformity after tumor resection or traumatic injury (Kim 2010). A smooth philtrum is also a characteristic feature of fetal alcohol syndrome (Kishi 2012).

Symmetry, normalcy, sexual dimorphism, and youthfulness are considered the classical elements of facial beauty (Rhoses 2006). Symmetry of face is the correspondence 
in size, shape, and relative position of parts on opposite sides of a dividing line or median plane or about a center or axis. This dividing line which is used to attained symmetry is known as the midline. It is the fundamental reference for all esthetic deviations. Therefore, knowledge of the midline will invariably result in a better understanding of facial and dental esthetics (Bashour 2006; Bidra 2009).

Nasal index (NI) is also common for evaluating type of nose. Nose is of different type and its morphology is influenced by the change of climate. Nasal Index is calculated by nasal width divided by nasal height multiplied by 100 . Nose can be different type. Broader nose are favored warm climates whereas narrower noses are favored in cold climates (Hall 1995; Risley 1915; Williams 1995).

Leptorrhine (Narrow nose) - NI $\leq 69.9$ : European

Mesorrhine (Medium) - NI $\leq 70$ - 84.9: Asian

Platyrrhine (Flat)-NI $\leq 85$ or more: most African.

Mathematically, Nasal Index (N. I. ) $=\frac{\text { Nasalwidth }(\mathrm{NW})}{\text { Nasal height }(\mathrm{NH})} \times 100,($ Anas \& Saleh 2014).

In anthropology and forensic medicine, the knowledge of nasal index is highly relevant in distinguishing the ethnic group and sex of individuals with unknown identity (Oladipo 2008; Porter 2003). The nasal index is also useful in the analysis of fossil remains as well as the study of living populations (Alex 1996). Nasal index measurement in healthy individuals is also useful for dysmorphologists in the early diagnosis of some dysmorphic syndrome like cleft lip and cleft palate which are associated with nose disorder during human embryonic period (Esomonu 2013).

There are very few available anthropometrical studies done on soft tissue morphology of adult face in Nepal. However, data are still lacking related nose and philtrum in Nepal. Literature search did not reveal any study on the nasal parameters of the Nepalese people of our region. It is planned to draw somatological data related to above mentioned parameters which would be further helpful, essential and useful tool to researcher, clinician, and forensic experts related to this type of study. This study was performed to establish morphological values related to nose and philtrum (face) and also determine the anatomical variation among sexes as well. 


\section{Material and Methods}

The study was conducted to determine and compare the nasal parameters of male and female Nepalese. After approval by the institutional ethics committee, this cross sectional study was performed among the medical students at Kathmandu Medical College, Nepal. Total 400 (200 males and 200 females) subjects aged 17-25 years were selected randomly for the study after obtaining their written informed consent.

\section{Measurements:}

The age, gender, weight, ethnicity, measurements of Nose length, Nose height, Philtrum length, Philtrum width and Columella width were determined. The height was measured in standing erect (with bare foot), anatomical position with standard height measuring instrument. Shoes and heavy socks were removed and weight was also measured. Parameters of Nose and Philtrum were measured by Electronic Digital Caliper $150 \mathrm{~mm}$ (6").

\section{Nose measurements:}

* Nose Height: Measured from nasion to sub nasal

* Length of Nose: Distance between Nasion to a point at tip of the nose in line with the upper edge of both Nostrils

* Depth of Nose: Distance from base of Columella to a point at tip of Nose in line with the upper edge of both nostrils.

* Width of Nose: Measured from ala to ala (most lateral points on each alar contour)

* Width of Columella of Nose: Measured at middle portion of Columella with a caliper.

\section{Philtrum measurements}

* Length of Philtrum- From the base of Columella to the midline depression of vermillion border.

* Width of Philtrum- Two points were marked at the base of the Philtrum; at junction of vertical ridge of Philtrum and vermillion border of upper lip. The width between these points was taken as the Philtrum width as illustrated in figure 1. 


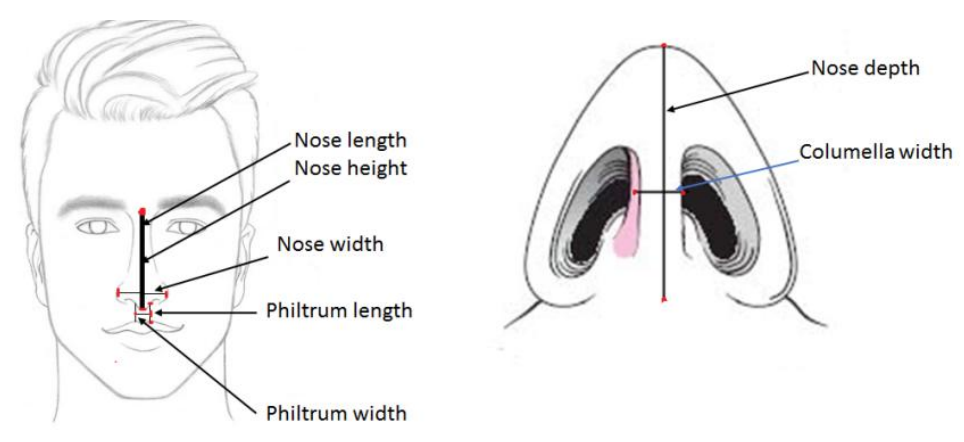

Figure 1: Measurements of Philtrum and Nose Parameters

\section{Statistical Analysis:}

Data were analyzed using IBM SPSS statistic version 22. Descriptive statistics of mean and standard deviation were used to summarize the data obtained. Two side $\mathrm{p}$ values were calculated using the paired sample T- test for observed variable. $\mathrm{P}$ values $<0.05$ were considered statistically significant.

\section{Observations and Results}

The results of this study were presented in Tables 1-5. Mean body weight was greater in males (66.13) as compared to the female (53.71) (Table 1). Similarly; Table 2 shows that the mean height was also greater in case of male subjects (168.09) as compare to their female counterparts (154.22).

The results obtained indicated a sexual dimorphism with significantly higher values of all the parameters in males as compared to corresponding females $(\mathrm{p}<0.05)$. Nasal index was obtained to be 69.68 in males and 74.20 in females. We concludes that the male nasal index lies between leptorrhine and mesorrhine type whereas in female nasal index is of mesorrhine type according to the classification of Nasal Index. Our results were compared with those obtained in other populations in Tables $6-9$. 
Table: 1: Comparison of mean weight between males and females

\begin{tabular}{|c|c|c|c|c|}
\hline Sex & Mean & SD & SE & P-value \\
\hline Males & 66.13 & 11.215 & 0.701 & 0.001 \\
\hline Females & 53.71 & 3.212 & 0.266 & 0.001 \\
\hline
\end{tabular}

Histogram : Comparision of Mean weight between males and $90 \quad$ females with SD

80

70

60

50

40

30

20

10

0

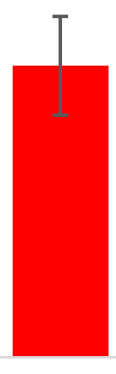

Males

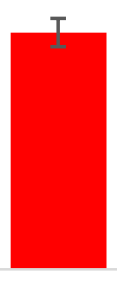

Females

Table: 2: Comparison of mean height between males and females

\begin{tabular}{|c|c|c|c|c|}
\hline Sex & Mean & SD & SE & P-value \\
\hline Males & 168.09 & 5.671 & 0.354 & 0.001 \\
\hline Females & 154.22 & 3.321 & 0.275 & 0.001 \\
\hline
\end{tabular}

Histogram:- Comparison of mean height between males and females

180
175
170
165
160
155
150
145
140
135

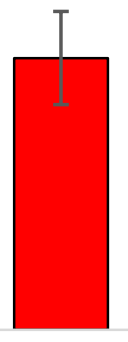

Males

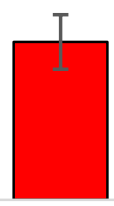

Females 
Table 3: Mean of Nose, Columella and Philtrum

\begin{tabular}{|l|c|c|c|}
\hline Parameters & Mean \pm SD & SE & p- value \\
\hline Nose Height & $50.813 \pm 4.53$ & 0.2261 & 0.001 \\
\hline Nose Length & $49.383 \pm 4.5683$ & 0.3009 & 0.001 \\
\hline Nose width & $36.204 \pm 4.0328$ & 0.2898 & 0.295 \\
\hline Nose depth & $19.8095 \pm 2.21992$ & 0.13325 & 0.001 \\
\hline Columella width & $6.323 \pm 0.6402$ & 0.03975 & 0.001 \\
\hline Philtrum length & $13.629 \pm 2.3567$ & 0.16 & 0.005 \\
\hline Philtrum width & $11.529 \pm 1.2714$ & 0.092 & 0.001 \\
\hline
\end{tabular}

Mean all parameters and SD

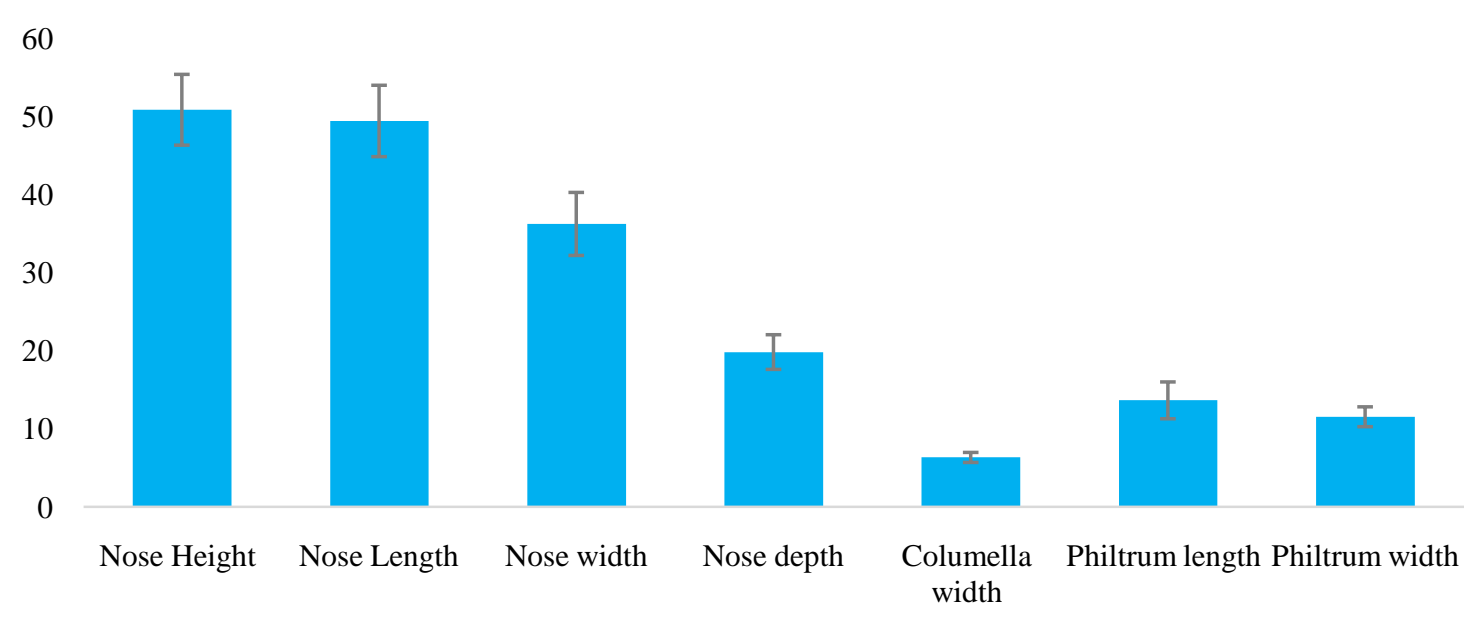


Table 4: Comparison of mean of Philtrum and Columella among the groups of males and females.

\begin{tabular}{|c|c|c|c|c|c|c|}
\hline \multirow{2}{*}{ Philtrum } & \multicolumn{3}{|c|}{ Males } & \multicolumn{3}{|c|}{ Females } \\
\hline & Mean & $\pm \mathrm{SD}$ & $\pm \mathrm{SE}$ & Mean & $\pm \mathrm{SD}$ & $\pm \mathrm{SE}$ \\
\hline Length & 14.300 & 2.1532 & 0.1346 & 12.452 & 2.2397 & 0.1854 \\
\hline Width & 11.857 & 1.0252 & 0.0641 & 10.954 & 1.4487 & 0.1199 \\
\hline
\end{tabular}

$P$ - Value $<0.001$

Mean of Philtrum

18

16

14

12

10

8

6

4

2

0

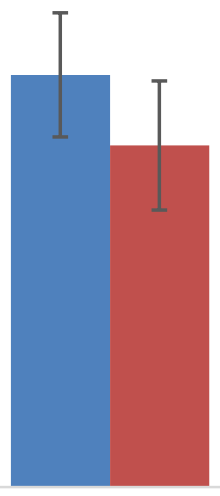

Males

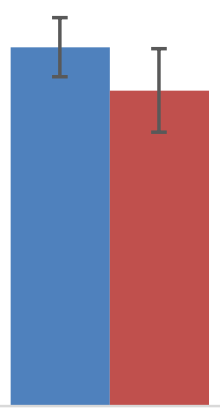

Females

- Length $\quad$ Width 
Table 5: Comparison of mean of Nose among the groups of males and females

\begin{tabular}{|c|c|c|c|c|c|c|c|c|}
\hline \multirow[t]{2}{*}{ Nose } & \multicolumn{4}{|c|}{ Males } & \multicolumn{4}{|c|}{ Females } \\
\hline & Mean & $\pm \mathrm{SD}$ & $\pm \mathrm{SE}$ & P-value & Mean & $\pm \mathrm{SD}$ & $\pm \mathrm{SE}$ & p-value \\
\hline Height & 52.18 & 4.24 & 0.267 & 0.001 & 48.41 & 4.02 & 0.033 & 0.001 \\
\hline Width & 36.363 & 4.1035 & 0.2565 & 0.001 & 35.925 & 3.9039 & 0.3231 & 0.001 \\
\hline Depth & 20.6695 & 2.01690 & 0.12606 & 0.001 & 18.3016 & 1.69689 & 0.14044 & 0.001 \\
\hline Length & 50.816 & 4.1884 & 0.2618 & 0.001 & 46.869 & 4.1078 & 0.3400 & 0.001 \\
\hline $\begin{array}{l}\text { Columella } \\
\text { width }\end{array}$ & 6.507 & 0.6531 & 0.0404 & 0.001 & 6.0000 & 0.4678 & 0.0387 & 0.001 \\
\hline
\end{tabular}

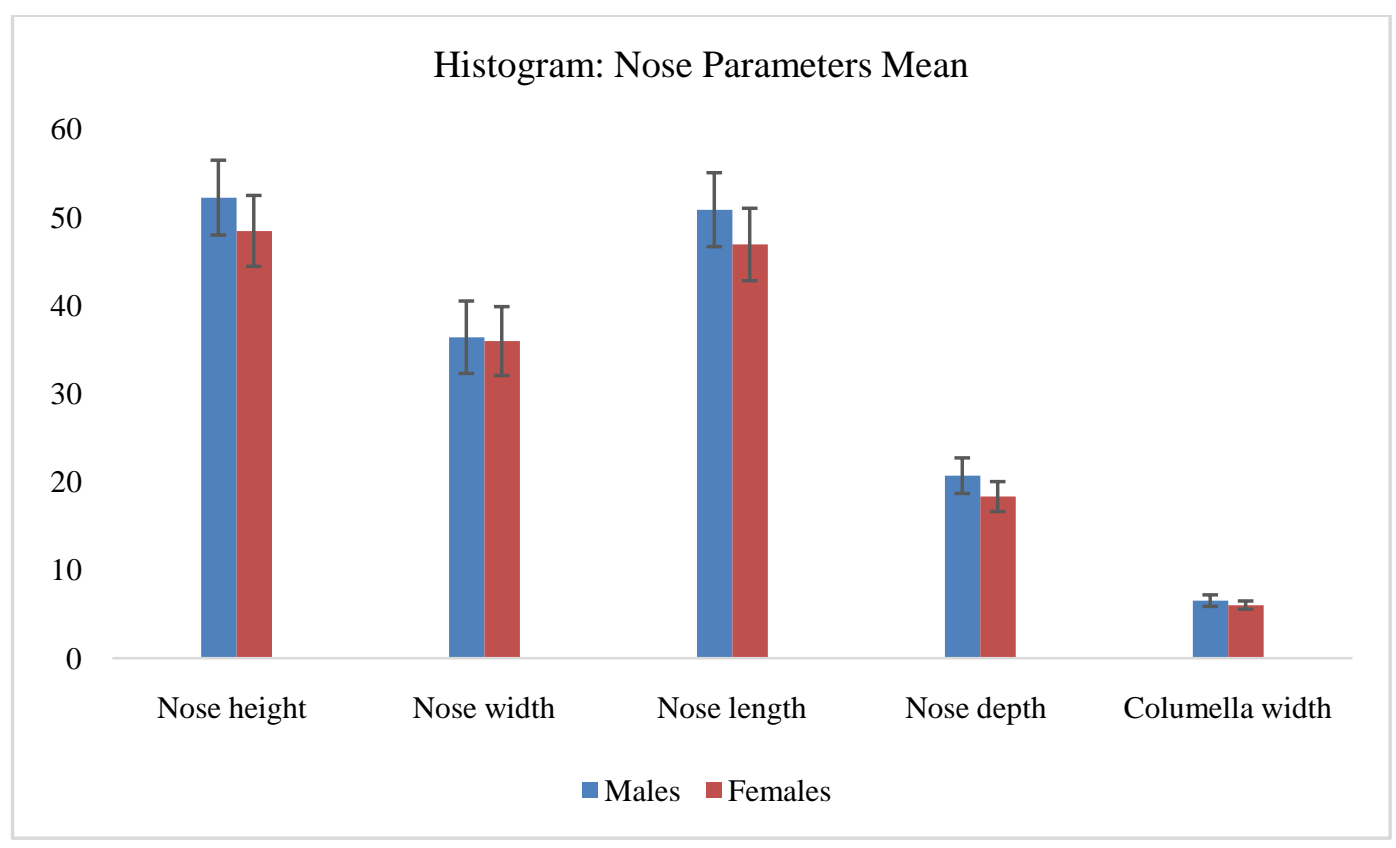




\section{Discussion}

The study was conducted in Nepalese populace of 17- 25 years of age. This study addresses a current void, i.e. the lack of a specific anthropometric study on the nasal and philtrum parameters of Nepalese populace: at our knowledge only one study was done on two particular communities living in eastern region in the Nepalese population (Shrestha et al. 2009). All this while, Southeast Asian plastic and reconstructive surgeons, head and neck surgeons, oral and maxillofacial surgeons, orthodontists, forensic investigators and other practitioners have not had any baseline anthropometric templates for the nasal and philtrum complex of the population of Nepal, referring instead to subjective visual "landmark" comparisons as their main tool.

Using established anthropometric measurement techniques to find universal nasal and philtrum focal points, this study's primary intention was to establish a baseline quantitative data of the Nepalese population. In the same time, this study aims to evaluate the normal data in the populations of Nepal related to nose and philtrum and also to determine the morphological variation in gender related to nose and philtrum since anthropometry deals with the variation in sexual dimorphism.

Regarding nose and philtrum, all the parameters were found to be of significance suggesting that, in general the measurements of these parameters are greater in males than in females. As there was no previous data on the Nepalese population, authors undertook the task of comparing their findings with those obtained in other populations.

Our results are consistent with those obtained in an Indian neighboring population, conducted by Sharma et al. (2014), who observed that the mean nasal depth among males and females were $20.87 \mathrm{~mm}$ and $17.72 \mathrm{~mm}$. We reported them to be $20.67 \mathrm{~mm}$ and 18.31 $\mathrm{mm}$ among males and females respectively. Sharma et al. also observed nasal index in Indian males and females and reported their nose as of mesorrhine type. In the present study too, the nasal index of whole Nepalese population fall in category of mesorrhine variety (71.24) but in males (70.00), nasal index was significantly lower than that of females (74.20). 
In Malay population, Ngeow \& Aljunid (2009) reported that nose width, height, philtrum length to be $41 \mathrm{~mm}, 51.6 \mathrm{~mm}$, and $13.1 \mathrm{~mm}$ in males where as in females these values were $37.3 \mathrm{~mm}, 54.1 \mathrm{~mm}$ and $12.2 \mathrm{~mm}$ respectively. In Nepalese population (present study) these values were $36.26 \mathrm{~mm}, 52.81 \mathrm{~mm}$, and $14.3 \mathrm{~mm}$ in males and $35.92 \mathrm{~mm}, 48.41$ $\mathrm{mm}$ and $12.45 \mathrm{~mm}$ respectively, in females. Hence, values found in females are higher in Malaysia as compare to those obtained in Nepal (present study) (Table 6).

Table 6: Comparison of Philtrum values between Nepaleses and Malays

\begin{tabular}{|c|c|c|c|c|}
\hline Populations & Sex & $\begin{array}{l}\text { Philtrum } \\
\text { length }\end{array}$ & Philtrum width & References \\
\hline \multirow{2}{*}{$\begin{array}{l}\text { Malays (from the } \\
\text { west Peninsular } \\
\text { Malaysia) }\end{array}$} & Males & $14.19(2.31)$ & $11.84(1.90)$ & \multirow[t]{2}{*}{ Othman et.al. (2016) } \\
\hline & Females & $12.71(1.95)$ & $10.40(1.14)$ & \\
\hline \multirow{2}{*}{$\begin{array}{l}\text { Malays (from } \\
\text { various states in } \\
\text { Malaysia) }\end{array}$} & Males & $14.19(2.31)$ & ---- & \multirow{2}{*}{$\begin{array}{l}\text { Ngeow \& Aljunid } \\
(2009)\end{array}$} \\
\hline & Females & $12.20(1.8)$ & ---- & \\
\hline \multirow{2}{*}{$\begin{array}{l}\text { Malays (from } \\
\text { different locations on } \\
\text { the Malaysian } \\
\text { peninsula) }\end{array}$} & Males & $13.81(2.69)$ & $13.11(2.31)$ & \multirow{2}{*}{$\begin{array}{l}\text { Al-Khatib et al. } \\
\text { (2012) }\end{array}$} \\
\hline & Females & 13.02(1.99) & $12.31(2.10)$ & \\
\hline \multirow{2}{*}{$\begin{array}{l}\text { Nepaleses } \\
\text { (from central Nepal) }\end{array}$} & Males & $14.300(2.1532)$ & $11.857(1.0252)$ & \multirow[b]{2}{*}{ Present study } \\
\hline & Females & $12.452(2.2397)$ & $10.954(1.4487)$ & \\
\hline
\end{tabular}

In another sample from Malay population, Al - Khatib at al. (2012) observed nose width $(40.27 \mathrm{~mm})$, nose height $(56.04 \mathrm{~mm})$ nose length $(46.86 \mathrm{~mm})$ in males and in females these values were $37.43 \mathrm{~mm}, 51.24 \mathrm{~mm}, 41.95 \mathrm{~mm}$ respectively. Philtrum parameters are given in Table 6. In comparison to their results, Nepalese population (present study) reported philtrum width $(11.857 \mathrm{~mm})$ and length $(14.3 \mathrm{~mm})$ in males and $12.45 \mathrm{~mm}, 10.954$ $\mathrm{mm}$ in females respectively. The results illustrate that philtrum length and width among males and females shows statistically significant difference (0.001). These values in Malay population do not match with our results on Nepalese population (Tables 6 - 9). 
Table 8 shows a comparison of the columella (in males and females) among different populations (Khandekar 2005) including that of the present study. This is clear that the columella width is highest in the sub-Saharan African or South Asian populations.

Table 9 illustrates the distribution of aspects height and nasal parameters in males and females. All nasal measurements and height are also significantly different across populations. The nasal width is largest in West Africans and smallest in North Europeans. Our findings are fairly consistent with previous observations. Differences in a phenotype can accumulate across populations simply due to genetic drift. In order to invoke positive directional selection, one must demonstrate that the variation across populations is more than that expected under genetic drift (Leinonen T, 2013).

Table 7: Comparison of nasal indices among worldwide populations.

\begin{tabular}{|l|l|l|}
\hline Population & Nasal index & References \\
\hline Sudroid & 89.8 & Franciscus \&Long 1991 \\
\hline Aryans & 83.0 & Franciscus \&Long 1991 \\
\hline Males onges & $72.3-97.7$ & Franciscus \&Long 1991 \\
\hline Females onges & $70.5-97.4$ & Franciscus \&Long 1991 \\
\hline Western Europeans & 69.9 & Heimaux \& Hartono 1980 \\
\hline Bantus & 85.0 & Heimaux \& Hartono 1980 \\
\hline German & 71 & Nichang 2004 \\
\hline Igbo males & 95.8 & Oladipo et al 2006 \\
\hline Igbo females & 90.8 & Oladipo et al 2006 \\
\hline Yoruba males & 90.0 & Oladipo et al 2006 \\
\hline Yoruba females & 88.1 & Oladipo et al 2006 \\
\hline Nepaleses Newar males & 70.0 & Present study \\
\hline Nepaleses Newar females & 74.2 & Present study \\
\hline
\end{tabular}

Table 8: Comparison of Columella width values found in our Nepalese sample with those obtained in other ethnic groups (Khanderkar et al. 2005)

\begin{tabular}{|l|l|c|l|l|l|l|}
\hline $\begin{array}{l}\text { Columella } \\
\text { width }\end{array}$ & $\begin{array}{l}\text { Nepaleses } \\
\text { (Present } \\
\text { study) }\end{array}$ & $\begin{array}{l}\text { Indians } \\
\text { (West } \\
\text { India) }\end{array}$ & $\begin{array}{l}\text { Indians } \\
\text { (South Indians) }\end{array}$ & Chinese & Europeans & $\begin{array}{l}\text { Sub-Saharan } \\
\text { or South Asian } \\
\text { populations }\end{array}$ \\
\hline Male & 6.51 & 5.7 & 6.00 & 6 & 8 & 9 \\
\hline Female & 6.00 & 5.7 & 6.00 & 7 & 6 & 7 \\
\hline
\end{tabular}


Table 9: Comparison of nasal parameters values by sex and population obtained in our Nepalese sample and other populations (Zaidi et al. 2018)

\begin{tabular}{|c|c|c|c|c|c|c|}
\hline Population & Sex & Height & $\begin{array}{l}\text { Nose } \\
\text { height }\end{array}$ & $\begin{array}{l}\text { Nose } \\
\text { Width }\end{array}$ & $\begin{array}{l}\text { Nose } \\
\text { depth }\end{array}$ & Nose length \\
\hline \multirow[t]{2}{*}{ W. African } & $\mathrm{M}$ & $\begin{array}{l}179.89 \\
(6.68)\end{array}$ & 51.31 & 45.31 & -- & 46.31 \\
\hline & $\mathrm{F}$ & $\begin{array}{l}164.68 \\
(8.61)\end{array}$ & 49.15 & 40.57 & -- & 43.82 \\
\hline \multirow[t]{2}{*}{ E. Asian } & $\mathrm{M}$ & $\begin{array}{l}173.02 \\
(6.79)\end{array}$ & 52.35 & 39.98 & -- & 47.14 \\
\hline & $\mathrm{F}$ & $\begin{array}{l}159.94 \\
(6.23)\end{array}$ & 48.78 & 36.60 & -- & 43.41 \\
\hline \multirow[t]{2}{*}{ N. European } & $\mathrm{M}$ & $\begin{array}{l}181.00 \\
(7.72)\end{array}$ & 51.59 & 35.66 & -- & 47.82 \\
\hline & $\mathrm{F}$ & $\begin{array}{l}167.15 \\
(6.70)\end{array}$ & 48.62 & 33.00 & -- & 44.78 \\
\hline \multirow[t]{2}{*}{ S. Asian } & $\mathrm{M}$ & $\begin{array}{l}173.91 \\
(6.13)\end{array}$ & 50.81 & 37.77 & -- & 46.59 \\
\hline & $\mathrm{F}$ & $\begin{array}{l}157.74 \\
(6.72) \\
\end{array}$ & 47.31 & 34.33 & -- & 43.57 \\
\hline \multirow[t]{2}{*}{$\begin{array}{l}\text { Nepaleses } \\
\text { (Present Study) }\end{array}$} & $\mathrm{M}$ & $\begin{array}{l}168.09 \\
5.671 \\
\end{array}$ & $\begin{array}{l}52.18 \\
4.24 \\
\end{array}$ & $\begin{array}{l}36.36 \\
4.10 \\
\end{array}$ & $\begin{array}{l}20.669 \\
2.02 \\
\end{array}$ & $\begin{array}{l}50.816 \\
4.1884 \\
\end{array}$ \\
\hline & $\mathrm{F}$ & $\begin{array}{l}154.22 \\
3.321 \\
\end{array}$ & $\begin{array}{l}48.41 \\
4.02 \\
\end{array}$ & $\begin{array}{l}35.92 \\
3.90 \\
\end{array}$ & $\begin{array}{l}18.3 \\
1.69 \\
\end{array}$ & $\begin{array}{l}46.869 \\
4.1078 \\
\end{array}$ \\
\hline
\end{tabular}

In a similar study from Malay population, Othman et al. (2013) reported nose width (39.59 $\mathrm{mm})$, nose height $(54.13 \mathrm{~mm})$ nose length $(46.86 \mathrm{~mm})$, philtrum width $(11.84 \mathrm{~mm})$ and philtrum length $(14.19 \mathrm{~mm})$ in males. In females these values were $36.67 \mathrm{~mm}, 49.20$ $\mathrm{mm}, 41.13 \mathrm{~mm}, 10.40 \mathrm{~mm}$ and $12.71 \mathrm{~mm}$ respectively. Their results are very close to our study as shown in Tables 4 and 5. In a study among Swiss population from central Europe, Zankl et al. (2002) reported that the value of philtrum was greater in males than females as it was noted in the present Nepalese population sample.

Shrestha et al. (2009) have investigated two particular communities, Rai and Limbo from eastern region in Nepal. They found that the nasal width in Rai (males $38.36 \mathrm{~mm}$, females $36.01 \mathrm{~mm}$ ) and Limbu (males $38.05 \mathrm{~mm}$ and females $37.73 \mathrm{~mm}$ ). These nasal width values are higher than those found in our study conducted in a central region of Nepal (males $36.36 \mathrm{~mm}$ and females $35.93 \mathrm{~mm}$ ). This reflects the particular origin of the Rai and Limbo communities: in fact they are considered as Mongoloid groups who have migrated from Tibet as well as from Northen Burma, Assam, Bhutan and Sikkim during 200 B.C. 
Smith et al. (2009) concluded that anatomical variations in facial soft tissue in human beings depend on genetic and environment factors. Buretic-Tomljanovic (2007) also observed in Croatia populations that these morphological variations may be due to genetic and environment factor such as climatic conditions which could alter the height and width of nose and philtrum parameters respectively.

Finally, it is clear that the previous conclusions and the present comparative analyses demonstrate that the variation of nasal parameters seems to be due to genetic and environmental factors: in fact Nasal index may vary with altitude and atmospheric humidity, and it displays a sexual dimorphism and ethnic variation. The investigation of nose shape evolution with respect to climate adaptation, while interesting anthropologically, is also relevant medically. As humans are becoming more of a global community, the study of local adaptation is becoming more important to understanding health risks involved in living in 'foreign' climates (Zaidi et al. 2018). Moreover, our results suggest that nose and philtrum parameters could be helpful anthropometrical tool in separating gender in existing geographical area. All nasal dimensions are found to be sexually dimorphic.

Nasal analysis is vital before performing rhinoplasty (plastic surgery). It is also important in forensic science. Hence research on the nasal parameters of various ethnic groups is very important. Our findings will be helpful in anthropometry, forensic medicine, and rhinoplasty and also provide a valuable data and background for future research evaluating the facial variation in same region.

\section{Conclusion}

Present study showed the significant value of all parameters in males and females. The mean nasal index of study population falls within the mesorrhine or medium nose type. The variation in all parameters is due to sexual dimorphism, genetic and climatic factors of Nepal. Values of all parameters were found to be higher in males. One clear observation is that all aspects of nose shape and philtrum, at least those considered here, are highly sexually dimorphic. The study is of immense value for further investigation in different 
region of Nepal. This is of high relevance to clinical anthropometry and forensic science and is also valuable in nasal anthropometry for formulation of normal data.

\section{Acknowledgement:}

We are thankful to all staff and colleagues of department of anatomy for their help and coordination and all the students who participated in this research study. We are also thankful to the ethical committee of KMC for approving this study. Finally, we would like to thank anonymous reviewers for providing helpful critique and comments on the first submission of this manuscript.

Conflicts of Interest: The authors declare no conflict of interest.

\section{References}

Al- Khatib A.R. (2010). Facial three dimensional imaging: an overview. Arch Orofac Sci. 5: $1-8$.

Alex F.R., Steven B. and Timothy G.L. (1996). Human Body Composition. $4^{\text {th }}$ ed. Human Kinetics Publisher. 167-172.

Anas I.Y., and Saleh M.S. (2014). Anthropometric Comparison of Nasal Indices between Hausa and Yoruba Ethnic Groups in Nigeria. Journal of Scientific research and reports. 3(3):437-444.

Bashour M. (2006). History and current concepts in the analysis of facial attractiveness. Plat Reconstr Surg. 118: 741-56.

Bidra A.S., Thomas D., Agar J.R. and Neace P. et al. (2009). The relationship of facial anatomical landmarks with midlines of the face and Mouth. The J. of Prosthet. Dent. 102: 94-103.

Buretic-Tomljanovic A., Giacometti J., Ostojic S. and Kapovic M. (2007). Sex-specific differences of craniofacial traits in Croatia: the impact of environment in a small geographic area. Ann Hum Biol. 34: 296- 314. doi: 10.1080/03014460701211017 PMID: 17612861. 
Esomonu U.G., Ude R.A., Lukpata P.U. and Nandi E.M. (2013). Anthropometrical study of the nasal index of Bekwara ethnic group of cross river state, Nigeria. International Research Journal of Applied and Basic Science. 5(10): 1262-1265.

Franciscus R.G. and Long J.C. (1991). Variation in human nasal height and breadth. Am J. Physical Anthropology. 419 - 427.

G. Madison.(2004) The passing of the great race. Language and nationality. Chapter 2, 2-4.

Hall R.L. and Hall D.A. (1995). Geographical Variation of native people along the pacific coast. Human biology 67(5); 407-427.

Hiernaux J. and Hartono D.B. (1980). Physical measurements of the adult Hadza of Tanzania. Ann Hum Biol. Jul-Aug;7(4):339-46.

Khanderkar B., Srinivasan S., Mokal N. and Thatte M.R. (2005). Anthropometric analysis of lip-nose complex in Indian population. Indian J. Plast. Surg. 38(2): 128-31.

Kim S.W., Jeong Y.W. and Cheon J.E. et al. (2010). Orbicularis oris muscle defects in philtral deformities in the repaired clef lip. J Korean Soc Plast Reconstr. Surg. 37:427-32.

Kishi N., Tanaka S., Iida S., et al. (2012). The morphology features and developmental changes of the philtral dimple: a guide to surgical intervention in case of cleft lip. J Craniomaxillofac Surg. 40: 215-22.

Know S.M., Park J.,Yang W.Y. et al. (2008). Reconstruction of philtral column with overlapping of orbicularis oris muscle flap in secondary cleft lip nose deformity. J Korean Soc Plast Reconstruct. Surg. 35:574-80.

Kohn L.A. (1991). The role of genetics in craniofacial morphology and growth. Annu Rev Anthropol. 20: 261-278. doi: 10.1146/annurev.an.20.100191.00140.

Leinonen T., Mc Cairns R.J.S., O'Hara R.B. and Merilä J. (2013). Q(ST)-F(ST) comparisons: evolutionary and ecological insights from genomic heterogeneity. Nat Rev Genet. Nature Publishing Group, a division of Macmillan Publishers Limited.14: 179-90. pmid:23381120

Ngeow W.C. and Aljunid S.T. (2009). Craniofacial Anthropometrics norms of Malays. Singapore Med. J. 50(5): 525.

Nichani J.R. (2004). Dimensional analysis - its role in our preoperative surgical planning of rhinoplasty. Clinical Otolaryngology and Allied Sciences. 5. 
Oladipo G., Udoaka A., Afolabi E. and Bob-Manuel I. (2008). Nasal Parameters of Itsekiris And Urhobos of Nigeria. The International Journal of Biological Anthropology. 3(1).

Oladipo G.S., Olabiyi A.O., Oremosu A.A, and Noronha C.C. (2007). Nasal indices among major ethnic groups in Southern Nigeria. Scientific Research and Essays, 2 (1): 2022.

Othman S.A., Ahmad R., Mericant A.F. and Jamaludin M. (2013). Reproducibility of facial soft tissue landmarks on facial images captured on a 3D camera. Aust Orthod J. 29: 58-65. PMID: 23785939.

Porter J.P. and Olson K.L. (2003). Analysis of the African American female nose. Plastic Reconstruction Surgery. 111(2): 627-628.

R.G. Franciscus, J.C. Long, (1991) Am. J. Physical Anthropol. 85(4): 419-427.

Rhoses G. (2006). The evolutionary psychology of facial beauty. Annu Rev Psychol. 57: 199-226.

Risley H.H. (1915). The people of Indian. Crooke W. Publishing Company. Philadelphia. $2^{\text {nd }}$ edition: $395-399$.

Sharma S.K., Jehan M., Sharma R.L., Saxena S., Trivedi A. and Bhadkarai V. (2014). Anthropometric Comparison of Nasal Parameters between Males and Females of Gwalior region. Journal of Dental and Medical Sciences. 13(5): 57-62.

Shrestha O., Bhattacharya S., Jha C.B., Shrestha S. and Shrestha U. (2009). Craniofacial anthropometric measurements among Rai and Limbu community of Sunsari district of Nepal. Nepal Med Coll J. 11(3): 183-185.

Smith R., Zaitoun H., Coxon T., Karmo M., Kaur G. and Townsend G. et al. (2009). Defining new dental phenotypes using 3-D image analysis to enhance discrimination and insights into biological processes. Arch Oral Biol. 54 (suppl. 1): S118-S125. doi:10.1016/j.archoralbio. 2008. 05.018 PMID: 18644585.

Williams P.L., Warwick R., Dyson M. and Bannister L.K. (1995). Gray's Anatomy $37^{\text {th }}$ edition. Churchill Living stone London. 601-612.

Zaidi A.A., Mattern B.C., Claes P., McEvoy B. and Hughes C. et al. (2018). Correction: Investigating the case of human nose shape and climate adaptation. PLOS Genetics 14(1): e1007207. 
Zankl A., Eberle L., Molinari L. and Schinzel A. (2002). Growth charts for nose length, nasalprotrusion and philtrum length from birth to 97 years. Am. J. Med. Genet. 111(4): 388-91.

To cite this article:

Yadav S.K., Malla B.K., Srivastava A.K., Timsina R.P., Srivastava N., Kumar A. 2018. Anthropometric Study of Philtrum (Face) and other nasal parameters in Nepal International Journal of Modern Anthropology. 2(11): 163 - 180 DOI: http://dx.doi.org/10.4314/ijma.v2i11.8

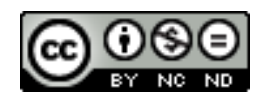

This article, as all articles published in this journal, is under The Creative Commons Attribution: Attribution-NonCommercial-NoDerivatives 4.0 International (CC BY-NC-ND 4.0). https://creativecommons.org/licenses/by-nc-nd/4.0/ 